\title{
Výpočty kritické rychlosti založené na smykových stopých zanechaných kolem s nulovým tlakem pneumatiky
}

\author{
Critical Speed Calculations Based on the Yaw Marks Deposited by the Wheel \\ with Zero Tyre Pressure
}

Jakub Zębala ${ }^{\mathrm{a}}$, Wojciech Wach ${ }^{\mathrm{a}}$, Piotr Ciępka ${ }^{\mathrm{a}}$, Robert Janczur ${ }^{\mathrm{b}}$

anstitute of Forensic Research, Krakov, Polská republika

${ }^{b}$ Cracow University of Technology, Krakov, Polská republika

\begin{abstract}
Abstrakt
V tomto článku jsou uvedeny výsledky analýzy smykových stop zanechaných vozidlem s nominálním tlakem pneumatik ve třech kolech a nulovým tlakem v jedné ze zadních pneumatik. Kromě popisu smykových stop je analýza kritické rychlosti založena na zakřivení smykových stop. Cíl výzkumu byl dosažen provedením měření na montážní desce a silničních zkoušek. Dále byly porovnány výsledky výpočtů, založených na geometrických vlastnostech smykových stop se skutečnými hodnotami získanými z měření jízdních parametrů vozidla.
\end{abstract}

Klíčová slova: smykové stopy, nulový tlak pneumatiky, kritická rychlost, pruhy.

\section{1. ÚVOD}

V postřetovém pohybu, kdy dochází ke stáčení vozidla a řidič nemá možnost ovládat vozidlo kvůli dosažení kritické rychlosti, mají smykové stopy charakteristický tvar šikmých pruhů $[1,3$, $4,5,6]$. V dnešní době, kdy jsou stále častějšími nehody bez brzdných stop, jsou smykové stopy významnými pro rekonstrukci nehod, jelikož jsou jedinými stopami, které umožňují rekonstrukci pohybu vozidla. Je třeba zdůraznit, že tyto stopy jsou rovněž zanechány vozidly, vybavenými mechatronickými systémy jako ABS a ESP $[1,6]$. Kritickou rychlost vozidla je možno vyhodnotit na základě zakřivení smykových stop [1, 2, 3, 4, 6, 8]. Odpovídající vzorec byl vyvinut pro pohyb vozidla s nominálním tlakem pneumatik. Nicméně se často stává, že v důsledku kolize vozidel nebo kontaktem s ostrým prvkem poškozeného vozidla dojde k poškození pneumatiky, což vede ke kompletní ztrátě

\begin{abstract}
This article presents the results of an analysis of the yaw marks left by a car with normal pressure in three tyres and zero pressure in one rear tyre. Apart from the description of yaw marks, vehicle critical speed on the basis of yaw mark curvature is determinated in the analysis. The aim of the research was reached by performing bench and road tests. Next, the results of calculations done on the basis of yaw marks geometrical features are compared with the real values known from the measurements of car motion parameters.
\end{abstract}

Keywords: yaw marks, zero tyre pressure, critical speed, strations.

tlaku v pneumatice. Předběžné testy s jedním vypuštěným kolem na vozidle prokázaly, že smykové stopy vznikají i tímto způsobem, nicméně se liší od stop, na základě kterých lze určit rychlost vozidla a zásahy řidiče do řízení [13]. Rozdíl vyplývá z mnohem větší boční deformace u pneumatiky se sníženým tlakem, smýkající se přes ráfek kvůli bočním sílám, působícím při pohybu vozidla. I přesto, že se řada studií a výzkumů zabývá analýzou smykových stop, nejsou dostupné žádné informace o tom, zda je možné určit kritickou rychlost vozidla na základě analýzy stop, zanechaných vypuštěnými pneumatikami. Vyřešení tohoto problému bylo možné pouze provedením jízdních zkoušek s vozidly, kdy jedno kolo mělo vypuštěnou pneumatiku. Takové testy byly provedeny $\mathrm{v}$ rámci výzkumného projektu Institutu forenzního výzkumu v Krakově (PL). Tyto zahrnovaly analýzu smykových stop zanechaných vozidlem s jedním zadním vypuštěným kolem. 


\section{VZOREC KRITICKÉ RYCHLOSTI}

Při rekonstrukci dopravních nehod je tzv. vzorec kritické rychlosti běžně používán k určení rychlosti vozidla na začátku smykových stop zanechaných na povrchu vozovky

$$
v=\sqrt{\mu g r},
$$

kde:

$\mu$

součinitel adheze mezi vozovkou a pneumatikou, tíhové zrychlení,

poloměr zatáčky $[\mathrm{m}]$.

Tato závislost je určena na základě provedení kruhové zkoušky na hranici adheze, kde je průměrný poloměr stop uvažován o stejné velikosti, jako je poloměr kruhu.

\section{PŘEDBĚŽNÁ ANALÝZA SMYKOVÝCH STOP}

Tento výzkum byl inspirován předchozím výzkumem autorů, týkajícím se předjíždění vozidel, u kterých bylo jedno kolo vypuštěné, kdy výsledky byly prezentovány na konferenci EVU ve Florencii [13]. Na betonovém povrchu zanechala vypuštěná pneumatika stopy, jejichž analýza byla omezena pouze na měření

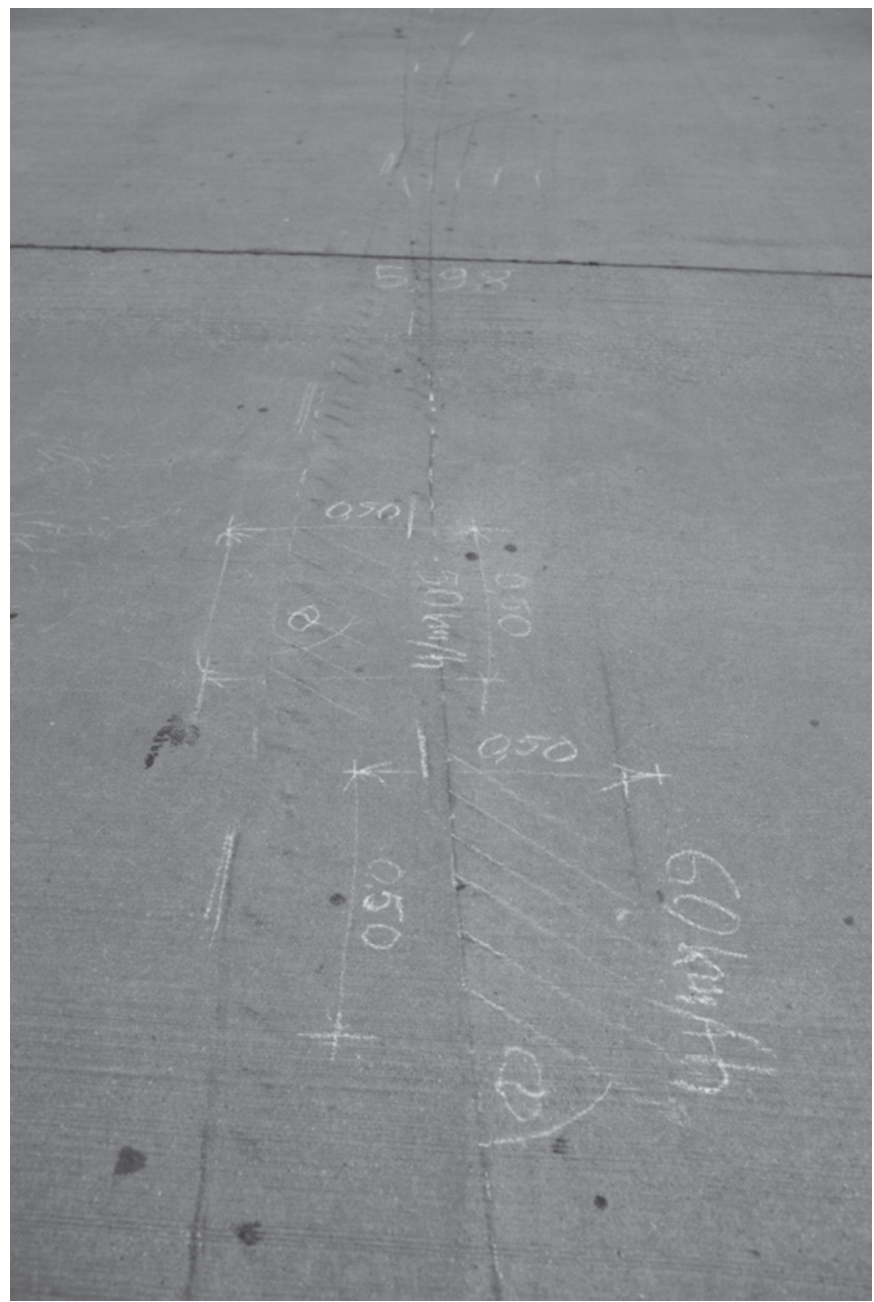

geometrie. Pro stopy byly charakteristické šikmé pruhy, které vznikly v důsledku př́čných sil, působících na kolo vozidla (obr. 1)

Přesné měření rozestupů pruhů, vzniklých po průjezdu vypuštěné pneumatiky prokázaly, že tyto rozestupy neodpovídaly rozestupům drážek na běhounu pneumatiky (obr. 2). Průměrné rozestupy pruhů byly v řádu $0,10 \mathrm{~m}$, kdežto rozestupy mezi drážkami na běhounu pneumatiky dosahovaly cca $0,03 \mathrm{~m}$. Dalším podstatným znakem stopy, zanechané vypuštěnou pneumatikou, byla tenká čára vedle pruhů (obr. 1). Tyto čáry se lišily svou intenzitou a vždy se nacházely na vnější straně pruhů. Počátek takovéto stopy byl velmi nápadný a byl viditelný ještě předtím, než se objevily charakteristické pruhy.

\section{CÍL VÝZKUMU}

Cílem výzkumu byla analýza smykových stop, zanechaných jedním ze zadních kol vozidla s vypuštěnou pneumatikou, za účelem ověření možnosti určení kritické rychlosti vozidla. Toho bylo dosaženo provedením měření na montážní desce a silničních testů, během kterých byly zaznamenávány jízdní parametry vozidla. Výsledky výpočtů, založených na geometrických parametrech smykových stop, byly porovnány se skutečnými hodnotami, získanými měřením parametrů pohybu vozidla.
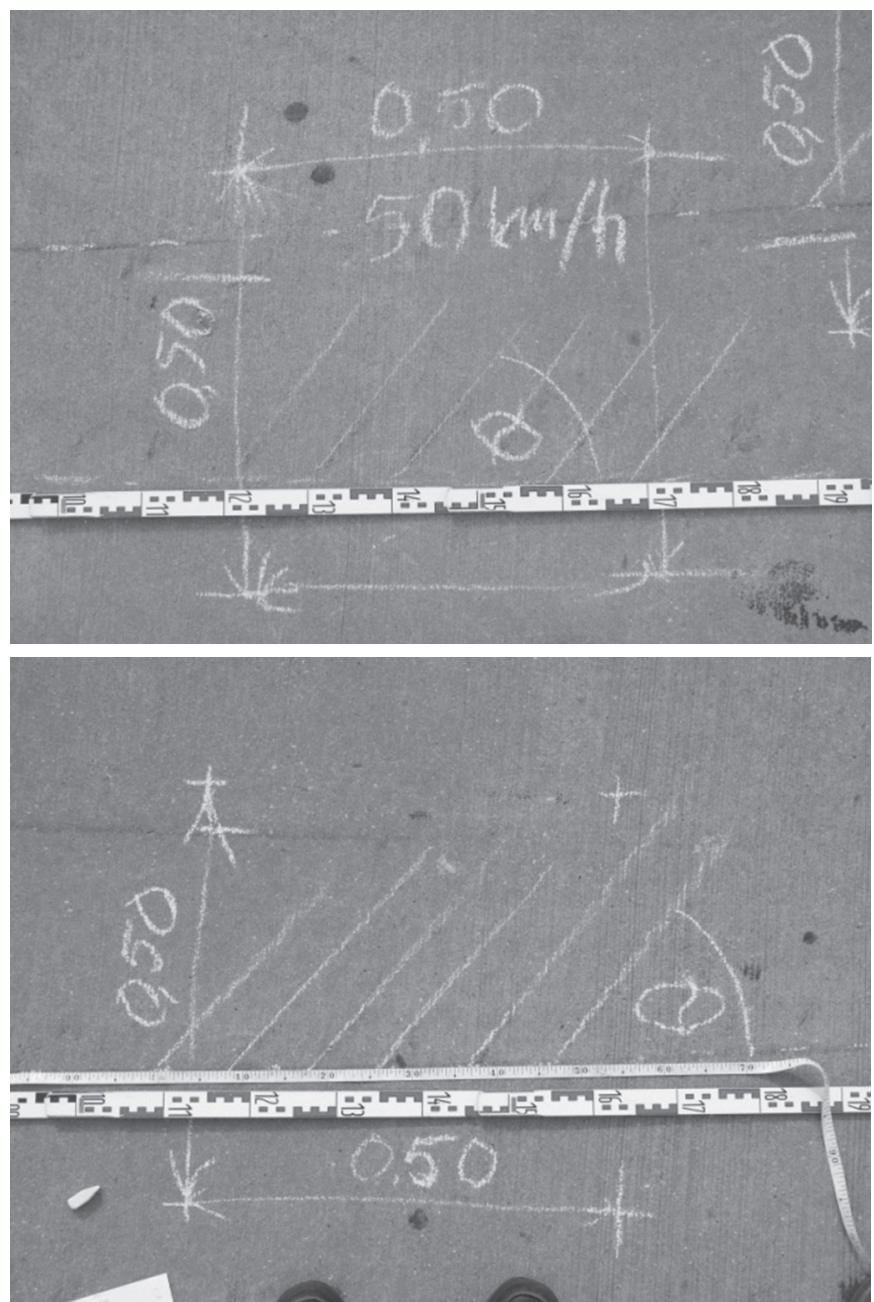

Obr. 1 Smykové stopy zanechané kolem s vypuštěnou pneumatikou-měrení rozměrů pruhů.

Fig. 1 Yaw marks from a wheel with zero pressure-measurement of striations geometry. 


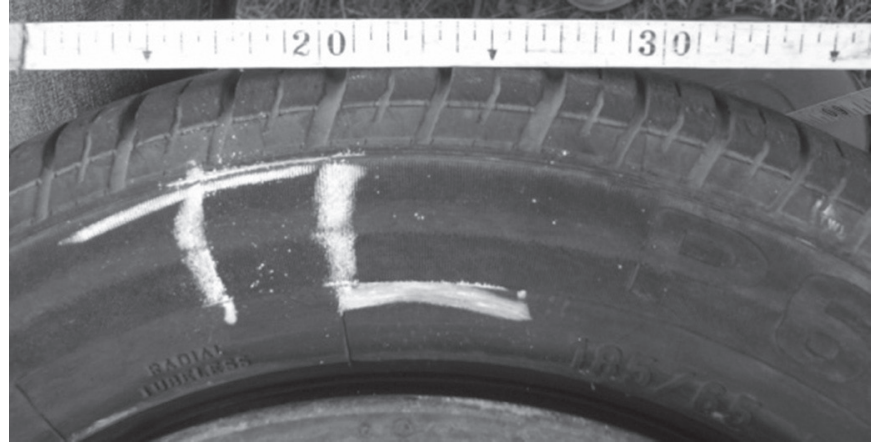

Obr. 2 Prvky dezénu na běhounu vypuštěné pneumatiky, která zanechala stopy, znázornèné na obr. 1.

Fig. 2 Tread elements on the shoulder of the tyre with zero pressure which deposited the mark shown in Fig. 1.

\section{PODMÍNKY TESTŮ}

Jízdní zkoušky byly provedeny na suchém živičném povrchu vozovky v létě. Rozjezd vozidla proběhl na prímém úseku vozovky, poté řidič zabočil ostře doleva. Během pohybu po oblouku řidič ani nezrychloval ani nezpomaloval; poté, co započal zatáčení, udržoval

Tab. 1 Technické údaje testovaného vozidla Tab. 1 Technical data of tested car.

\begin{tabular}{lcc}
\hline \multicolumn{1}{c}{ Proměnné } & \multicolumn{2}{c}{ Hodnota } \\
\hline Rozložení hmotnosti vozidla na kola: & & \\
levé přední & 465 & $\mathrm{~kg}$ \\
pravé přední & 475 & $\mathrm{~kg}$ \\
pravé zadní & 350 & $\mathrm{~kg}$ \\
levé zadní & 345 & $\mathrm{~kg}$ \\
Vzdálenost těžiště od přední osy & 1,148 & $\mathrm{~m}$ \\
Výška těžiště & 0,55 & $\mathrm{~m}$ \\
Rozvor & 2,703 & $\mathrm{~m}$ \\
Převodový poměr převodovky ř́izení & $16: 1$ & \\
\hline
\end{tabular}

konstantní úhel natočení volantu, dokud nedošlo k zastavení vozidla. Testy byly provedeny s nominálním tlakem pneumatik, doporučeným výrobcem vozidla, ve třech pneumatikách, pravá zadní pneumatika byla vypuštěna. Následující parametry byly měřeny: podélná rychlost a pozice vozidla, stáčivé rychlosti, klonění a klopení vozidla a úhel natočení volantu.

\section{TESTOVANÉ VOZIDLO}

Pro testování bylo použito vozidlo Volkswagen Passat kombi 2.0 TDI (rok výroby 2003) s pneumatikami Firestone Fire FireHawk 195/65R15 91T. Před jízdními zkouškami byla provedena měření na montážní desce, kterými bylo určeno rozložení hmotnosti na jednotlivá kola, výška těžiště a jeho vzdálenost od přední osy vozidla, rozvor a prrevodový poměr v rrízení.

\section{MĚŘICÍ P̌̌íSTROJE}

Tab. 2 uvádí parametry přístrojů a senzorů použitých při jízdních zkouškách [11]. Navíc byla použita data, získaná ze sběrnice CAN vozidla Volkswagen ,a to konkrétně otáčky kol, která zanechávala stopy, což umožnilo výpočet kritické rychlosti tohoto kola.

Pohyb vozidla při testech byl zaznamenáván třemi digitálními vysokorychlostními kamerami včetně CASIO EX-F1 a Sony HDRCX730E. Po každém průjezdu byl dokumentován stav vypuštěné pneumatiky (obr. 3).

\section{PARAMETRY POHYBU VOZIDLA PODÉL SMYKOVÝCH STOP}

Za účelem provedení analýzy smykových stop byly provedeny dvě jízdy s vypuštěnou pravou zadní pneumatikou (jízdy č. 1 a 2). Během jízd byly pořízeny fotografie smykových stop. Po kompenzaci zkreslení pomocí fotogrammetrické transformace fotografií pomocí programu PC-Rect 4.1 a dále po zkombinování

Tab. 2 Veličiny měřené při jizdnich zkouškách.

Tab. 2 Measurement units used in road tests.

\begin{tabular}{|c|c|c|c|}
\hline Měřicí zařízení & Parametry & Rozsah měření & Přesnost měření \\
\hline \multirow{2}{*}{ 2-osý optický senzor Correvit Corrsys ${ }^{\circledR}$ S-CE } & Podélná rychlost & $0-350 \mathrm{~km} / \mathrm{h}$ & $0,03 \mathrm{~m} / \mathrm{s}$ \\
\hline & Př́íčná rychlost & $\pm 225 \mathrm{~km} / \mathrm{h}$ & $0,03 \mathrm{~m} / \mathrm{s}$ \\
\hline \multirow{2}{*}{ Inerciální systém Crossbow’s 440 Series } & Zrychlení & $\pm 4,0 \mathrm{~g}$ & $<0,5 \mathrm{mg}$ \\
\hline & Úhlová rychlost & $\pm 200 \% \mathrm{~s}$ & $<0,02 \%$ \\
\hline Univerzální měřicí volant Kistler Group & Úhel natočení volantu & $\pm 1250^{\circ}$ & $\leq 0,1^{\circ}$ \\
\hline \multirow{3}{*}{ GPS Data Logger (RLV B3iR10G10) } & Obvodová rychlost & $0,1-447 \mathrm{~m} / \mathrm{s}$ & $0,03 \mathrm{~m} / \mathrm{s}$ \\
\hline & Směr jízdy & $0-360^{\circ}$ & $0,1^{\mathrm{o}}$ \\
\hline & Vzdálenost & & $0,05 \%<50 \mathrm{~cm} / \mathrm{km}$ \\
\hline \multirow{2}{*}{ Inerciální měřicí jednotka (RLVBIMU03) } & $\begin{array}{l}\text { Podélné, příčné } \\
\text { a vertikální zrychlení }\end{array}$ & $\pm 1,7 \mathrm{~g}$ & $0,01 \mathrm{~g}$ \\
\hline & $\begin{array}{l}\text { Úhlová rychlost: klonění, } \\
\text { klopení a zatáčení }\end{array}$ & $\pm 150 \% \mathrm{~s}$ & $0,01 \%$ \\
\hline
\end{tabular}



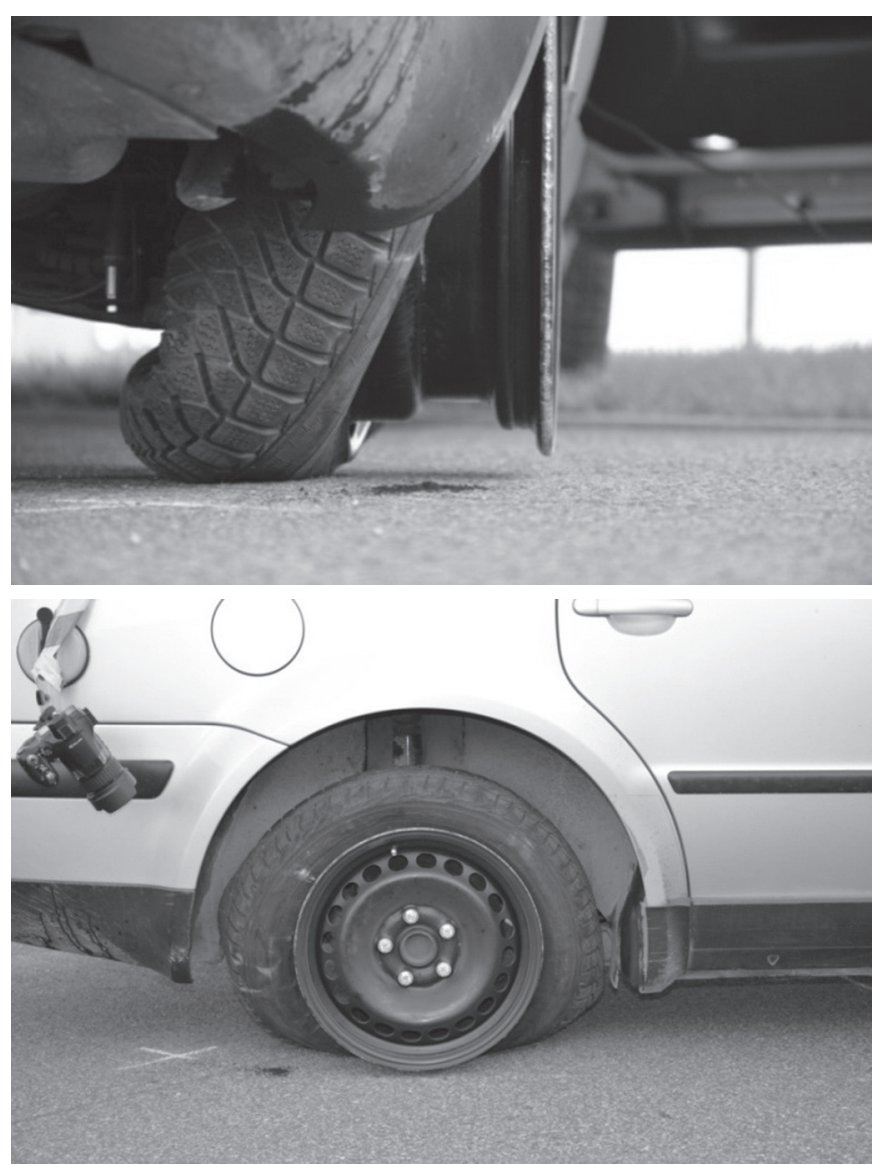

Obr. 3 Pravá zadní vypuštěná pneumatika po testu. Fig. 3 Right rear wheel after test with zero pressure. příslušných fotografií byly vytvořeny ortofotomapy skutečných smykových stop. Při každé jízdě byly měřeny jízdní parametry vozidla. Po zpracovaní naměřených dat, které následovalo po postupu popsaném $\mathrm{v}$ [12], byly získány skutečné parametry pohybu vozidla $\mathrm{v}$ inerciálním, tj. globálním souřadném systému. Simulace pohybu vozidla, provedená na základě těchto údajů, byla provedena $\mathrm{v}$ programu $\mathrm{PC}-\mathrm{Crash}$ proti pozadí $\mathrm{s}$ ortofotomapou, na které byly zaznamenány skutečné smykové stopy (obr. 4 a 5).

Korelací parametrů pohybu vozidla, získaných pomocí měření se skutečnými stopami, bylo možno přesně určit pohyb vozidla v každé poloze sledované smykové stopy.

\section{KRITICKÁ RYCHLOST TESTOVANÉHO VOZIDLA}

Na základě měření zakřivení smykových stop byla vypočtena kritická rychlost na začátku odhalených stop pomocí rovnice (1); poloměr otáčení $R$ byl vypočten ze závislosti:

$$
R=\frac{C^{2}}{8 m}+\frac{m}{2}
$$

kde:

C délka tětivy [m],

$m \quad$ výška úseče (měřeno od středu tětivy) [m].

Velikost součinitele adheze $\mu$ byla určena na základě provedení několika brzdných zkoušek. Zaznamenané hodnoty zpomalení byly zpracovány pomocí nízkopásmového filtru Butterworth CFC 180, následně normou SAE J211 [10] (obr. 6) a dále bylo

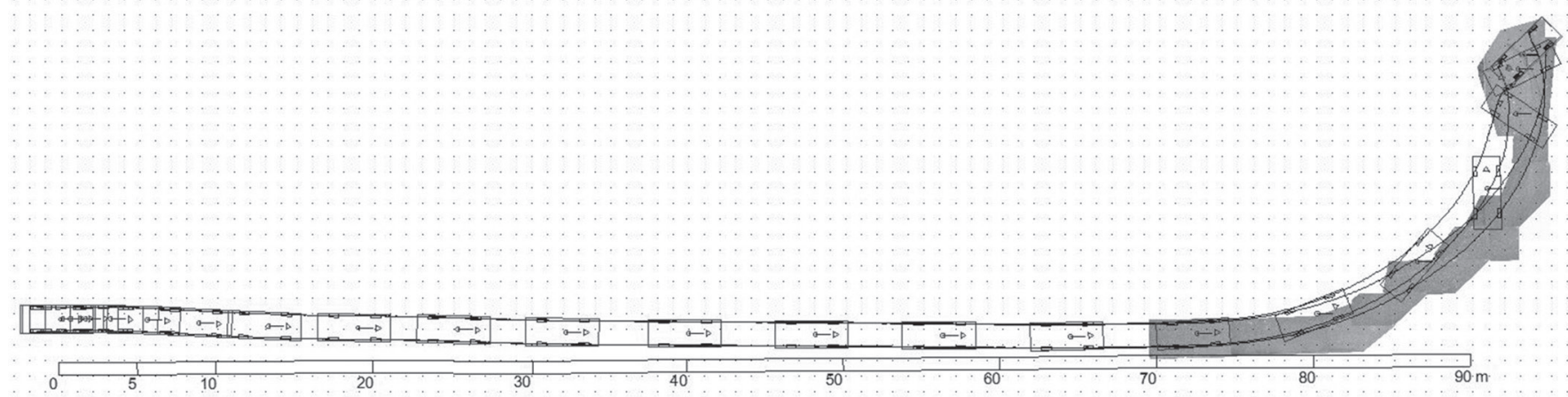

Obr. 4 Simulovaný pohyb vozidla na pozadi se skutečnými smykovými stopami pro jízdu č. 1.

Fig. 4 Reconstructed vehicle motion presented against the background of real yaw marks for test No. 1 .

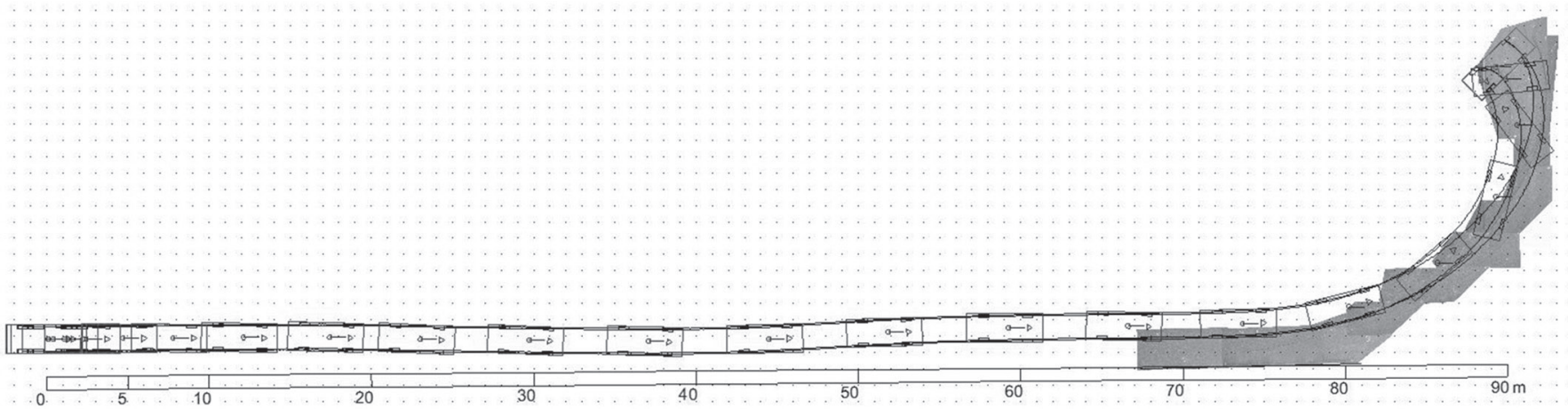

Obr. 5 Simulovaný pohyb vozidla na pozadi se skutečnými smykovými stopami pro jizdu č. 2.

Fig. 5 Reconstructed vehicle motion presented against the background of real yaw marks for test No. 2. 


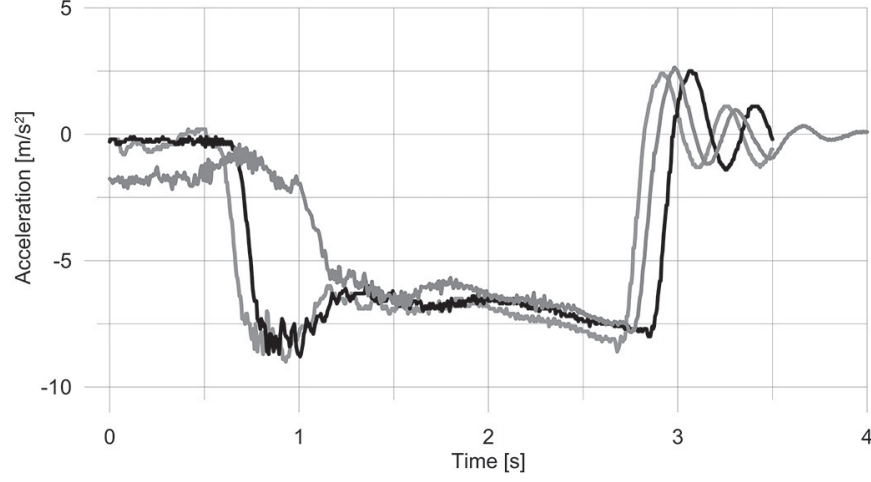

Obr. 6 Průběhy zpomaleni tři přikladů brzdných zkoušek.

Fig. 6 Time histories of deceleration for three examples of braking tests.

vyhodnoceno MFDD (střední plné brzdné zpomalení), definované v předpisu ECE č. 13, vypočítané pomocí vzorce [7]

$$
M F D D=\frac{v_{b}^{2}-v_{e}^{2}}{25,92\left(S_{e}-S_{b}\right)},
$$

kde:

$v_{o} \quad$ výchozí rychlost vozidla $[\mathrm{km} / \mathrm{h}]$,

$v_{b} \quad$ rychlost vozidla prri $0,8 v_{o}[\mathrm{~km} / \mathrm{h}]$,

$v_{e} \quad$ rychlost vozidla při $0,1 v_{o}[\mathrm{~km} / \mathrm{h}]$,

$S_{b} \quad$ vzdálenost ujetá mezi $v_{o}$ i $v_{b}[\mathrm{~m}]$,

$S_{e} \quad$ vzdálenost ujetá mezi $v_{o}$ i $v_{e}[\mathrm{~m}]$.

Střední hodnota součinitele adheze, zjištěná na základě několika brzdných zkoušek se zablokovanými předními koly, byla 0,69 ; tato hodnota pak byla použita pro stanovení kritické rychlosti. Pro stanovení kritické rychlosti bylo použito několik délek tětiv, které splňovaly podmínky aplikace závislosti (1), včetně podmínky, že rozdělení předních a zadních stop pneumatik přes délku tětivy by nemělo přesáhnout polovinu rozchodu vozidla [5]. Výšky úsečí př́slušných tětiv byly měřeny na obrázcích s rekonstruovaným průběhem stop (obr. 7 a 9). Vypočtená kritická rychlost pro vybrané tětivy a relativní chyba ve vztahu ke skutečným hodnotám, měřeným v průběhu jízdních zkoušek, jsou uvedeny v tab. 3 a 4.

Výsledky výpočtů kritické rychlosti vozidla založené na zakřivení smykových stop svědčí o tom, že tato metoda může být rovněž

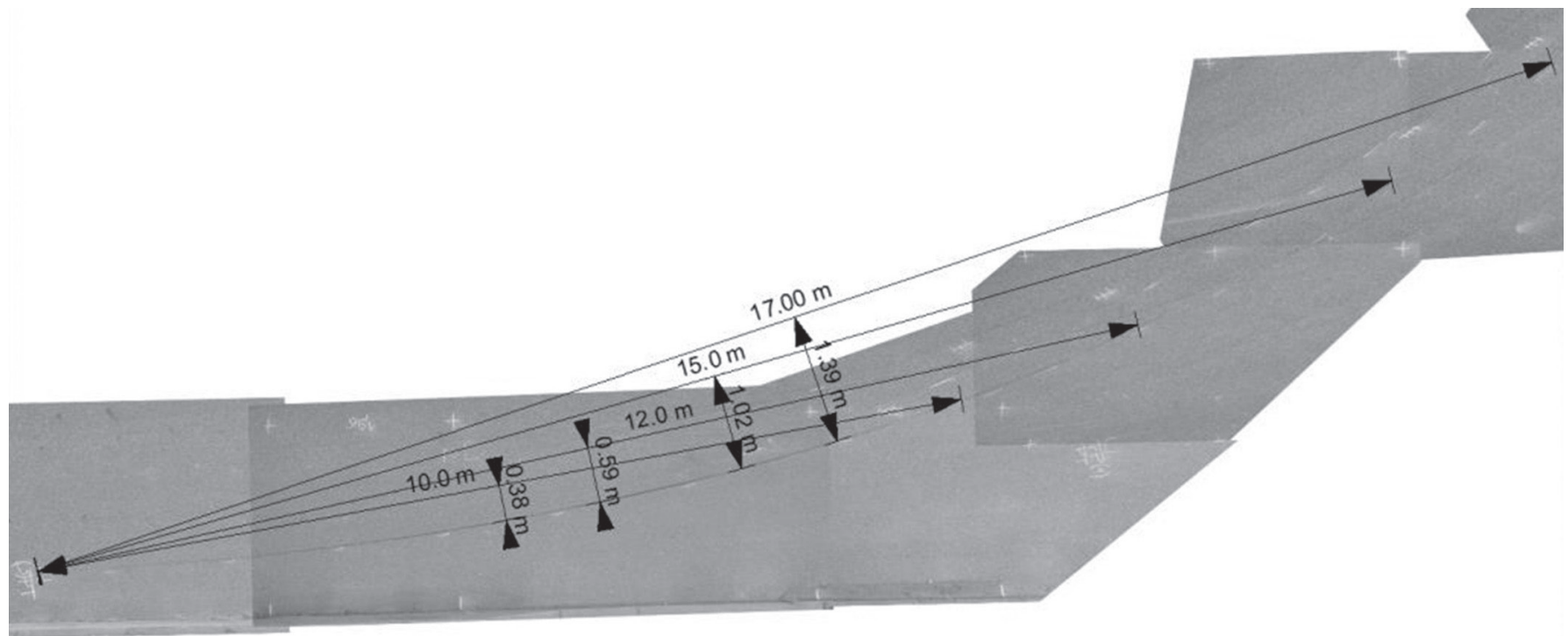

Obr. 7 Měreni tětiv a výšek úseči stop zanechaných při průjezdu č. 1 .

Fig. 7 Measurement of chords and middle ordinates lengths for the mark deposited in test No. 1 .

Tab. 3. Výsledky jízdní zkoušky č. 1.

Tab. 3. Results for test No. 1 .

\begin{tabular}{lcccc}
\hline $\boldsymbol{k}[\mathrm{m}]$ & 10 & 12 & 15 & 17 \\
$c[\mathrm{~m}]$ & 0,38 & 0,59 & 1,02 & 1,39 \\
$\boldsymbol{r}[\mathrm{m}]$ & 33 & 31 & 28 & 27 \\
$\boldsymbol{v}[\mathbf{k m} / \mathbf{h}]$ & 54 & 52 & 50 & 49 \\
$\operatorname{chyba} \boldsymbol{v}[\%]$ & 13 & 9 & 4 & 2 \\
\hline
\end{tabular}

Tab. 4. Výsledky jízdní zkoušky č. 2.

Tab. 4. Results for test No. 2 .

\begin{tabular}{lcccc}
\hline $\boldsymbol{k}[\mathrm{m}]$ & 10 & 12 & 15 & 16 \\
$\boldsymbol{c}[\mathrm{m}]$ & 0,54 & 0,88 & 1,54 & 1,87 \\
$\boldsymbol{r}[\mathrm{m}]$ & 23 & 21 & 19 & 18 \\
$\boldsymbol{v}[\mathbf{k m} / \mathbf{h}]$ & 45 & 43 & 41 & 40 \\
$\operatorname{chyba} \boldsymbol{v}[\%]$ & 13 & 7 & 2 & 0 \\
\hline
\end{tabular}

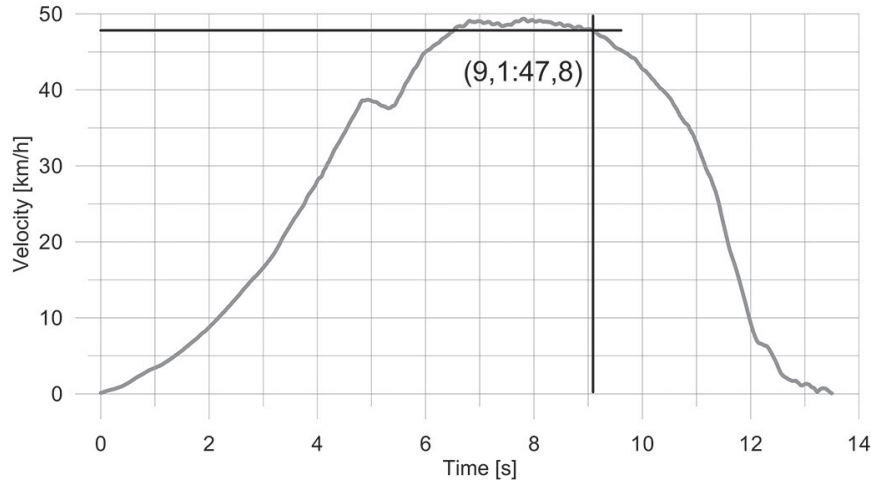

Obr. 8 Rychlost testovaného vozidla měřená během průjezdu č. 1 s vyznačením počátku smykové stopy.

Fig. 8 Velocity of tested vehicle recorded during test No. 1 with indicated point of the beginning of yaw mark. 


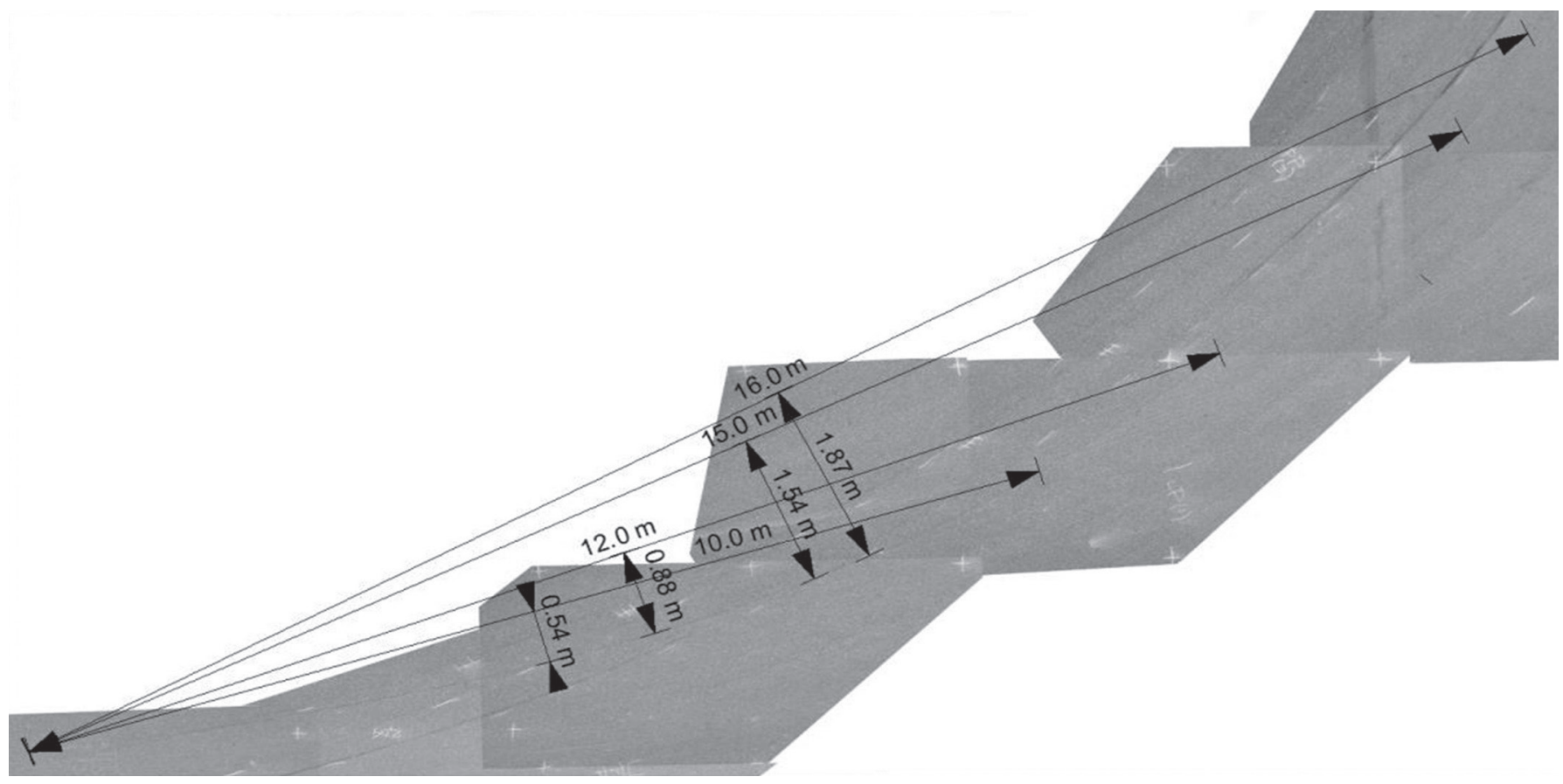

Obr. 9 Měrení tètiv a výšek úseči stop zanechaných při průjezdu č. 2.

Fig. 9 Measurement of chords and middle ordinates lengths for the mark deposited in test No. 2.

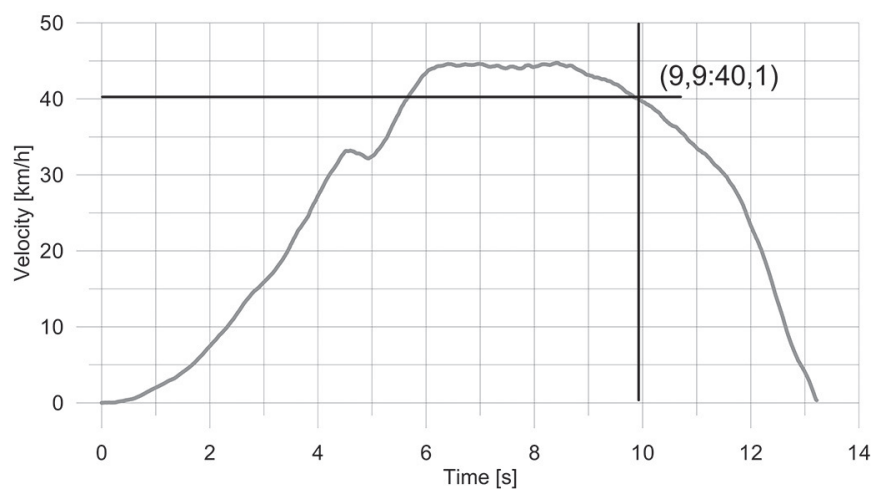

Obr. 10 Rychlost testovaného vozidla měrená během průjezdu č. 2 $s$ vyznačením počátku smykové stopy.

Fig. 10 Velocity of tested vehicle recorded during test No. 2 with indicated point of the beginning of yaw mark.

použita pro smykové stopy zanechané kolem s vypuštěnou pneumatikou. Vypočtená kritická rychlost byla v rozsahu nejistoty metody $\pm 10 \%$, když byla délka tětivy zakřivení stopy cca $15 \mathrm{~m}$ (tab. 3 a 4$)$.

\section{POHYB VOZIDLA S VYPUŠTĚNOU ZADNÍ PNEUMATIKOU}

Smykové stopy, zanechané pravým zadním kolem s vypuštěnou pneumatikou, rovněž odhalily pruhy a tenké, podélné stopy různé intenzity. Navíc byl během jízdních zkoušek poškrábán povrch vozovky ráfkem disku poté, co z něj sklouzla pneumatika (obr. 11). Stopy po kontaktu povrchu vozovky s ráfkem byly na vnější straně pruhů a tenké stopy.

Pro analýzu geometrie pruhů stop byly vybrány dvě sekce stop, vytvořených při první jízdní zkoušce: jedna na začátku stop

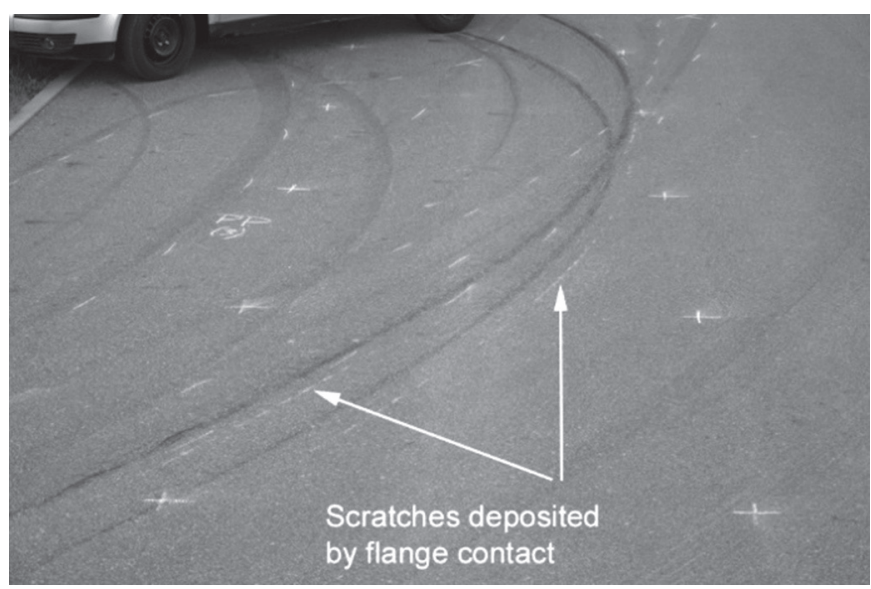

Obr. 11 Stopy zanechané pravým zadním vypuštěným kolem.

Fig. 11 Marks deposited by rear right wheel with zero pressure.

s pneumatikou pouze částečně sklouznutou z ráfku a další na konci stopy s plně sklouznutou pneumatikou (obr. 12).

V první sekci stopy byly identifikovány pravidelné proužky, vzdálenost mezi nimi byla přibližně $0,11 \mathrm{~m}$ (obr. 13). Poté, co pneumatika sklouzla $\mathrm{z}$ ráfku (druhá analyzovaná sekce stopy), se vzor pruhů změnil (obr. 14). pruhy byly delší a nepravidelné; vzdálenost mezi nimi, měřená podél stopy, se pohybovala od $0,10 \mathrm{~m}$ do $0,22 \mathrm{~m}$.

\section{DISKUSE VÝSLEDKŮ}

Získané výsledky naznačují, že kolo s vypuštěnou pneumatikou zanechává smykové stopy. Z analýzy těchto stop vyplývá, že nejsou identické po celé své délce. V některých místech vytvořily tenkou, prodlouženou stopu, pouze pruhy nebo jak tenké stopy, 


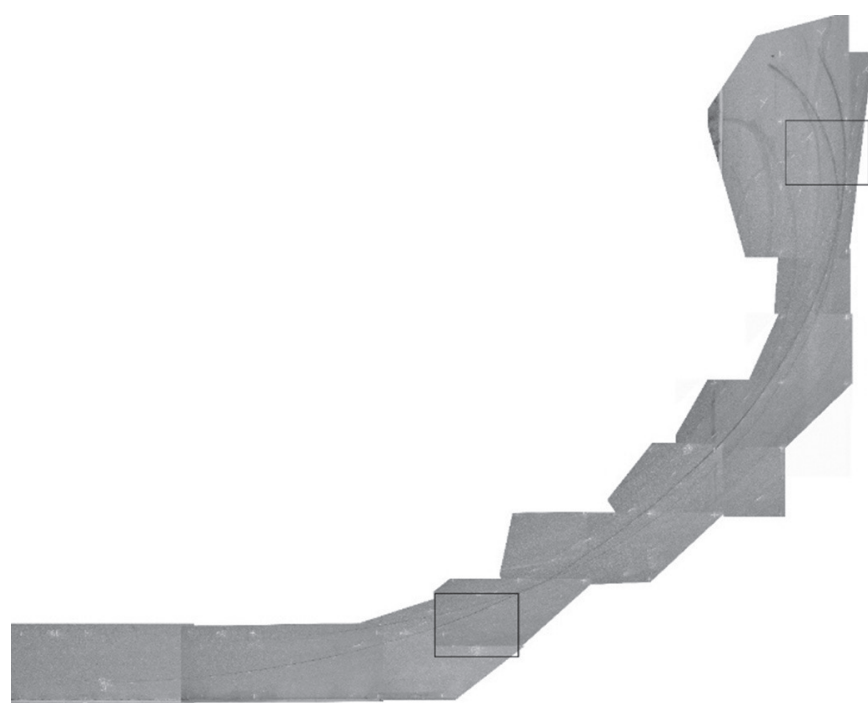

Obr. 12 Smykové stopy vozidla z 2. jízdního testu s výběry sekcí se stopami, zanechanými pravou zadni pneumatikou.

Fig. 12 Car yaw marks from test No. 2 with selected sections of marks made by rear right wheel.

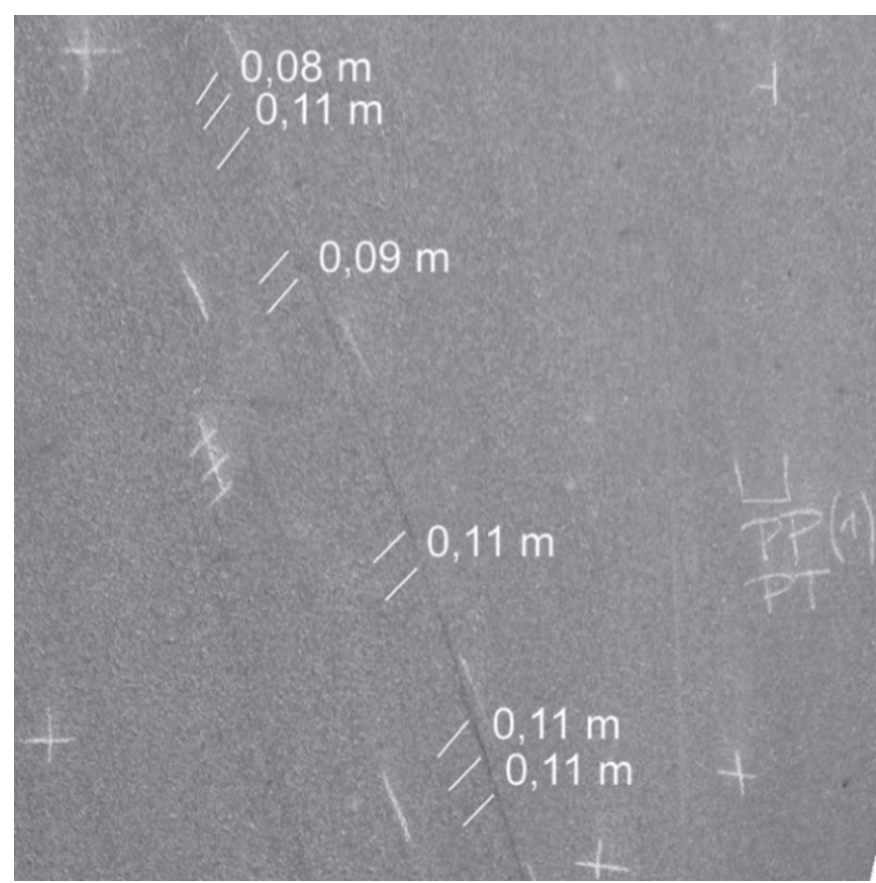

Obr. 13 První sekce smykových stop, zanechaná kolem s vypuštěnou pneumatikou, s vyznačenými pruhy.

Fig. 13 The first section of yaw mark made by a wheel with zero pressure with indicated striations.

tak pruhy a škrábance na povrchu vozovky. U pruhů se lišila jejich délka a také jejich rozteč. Geometrie stop kola s vypuštěnou pneumatikou se lišila od kola s nominálním tlakem pneumatiky. Rozteče pruhů stopy, vytvořené kolem s vypuštěnou pneumatikou byly podstatně větší, než rozteče drážek na běhounu pneumatiky, což naznačuje, že tato stopa neodráží pouze rozměry pneumatiky. Analýza videozáznamů, dokumentujících pohyb kola s vypuštěnou pneumatikou společněs geometrií stop umožňuje prohlásit, že tato stopa je způsobena vibrací kola, způsobenou navinutím pneumatiky pod ráfek v místě kontaktu s povrchem vozovky.

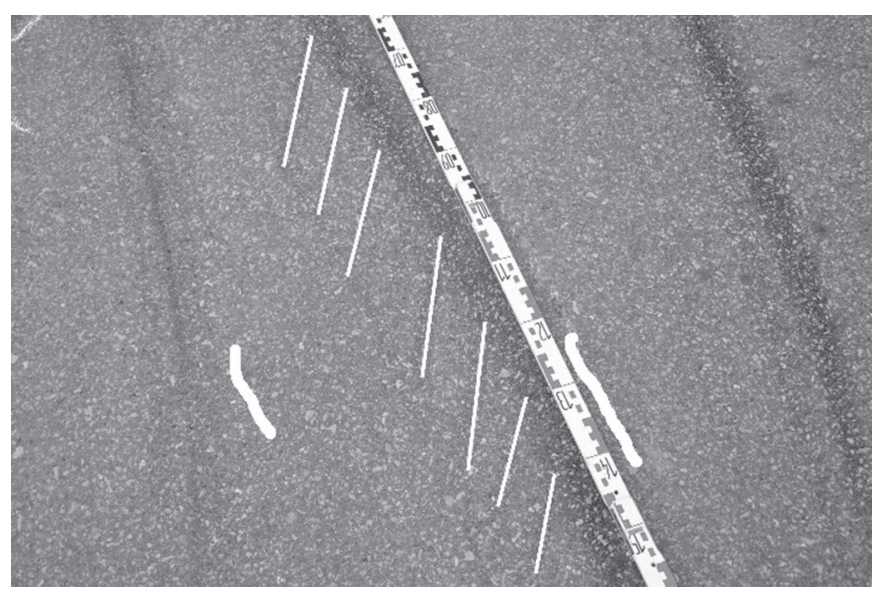

Obr. 14 Druhá sekce smykových stop zanechaná kolem s vypuštěnou pneumatikou s vyznačenými pruhy.

Fig. 14 The other section of yaw mark made by a wheel with zero pressure with indicated striations.

\section{ZÁV̌̌R}

Výsledky výpočtů kritické rychlosti vozidla, založené na zakřivení smykových stop naznačují, že tato metoda je použitelná rovněž pro smykové stopy, zanechané kolem s vypuštěnou pneumatikou.

Kolo s vypuštěnou pneumatikou zanechává smykovou stopu, jejíž geometrie se liší od smykové stopy, zanechané kolem s nominálním tlakem pneumatiky.

Rozteče mezi pruhy ve stopě, zanechané kolem s vypuštěnou pneumatikou jsou podstatně větší, než rozteče drážek v běhounu pneumatiky. Toto naznačuje, že tato stopa neodráží pouze rozměry pneumatiky a je způsobena vibracemi kola, způsobenými navinutím pneumatiky pod ráfek kola v místě styku kola s povrchem vozovky.

\section{LITERATURA}

[1] AMIRAULT, G., MACLNNIS, S. Variability of Yaw Calculations from Field Testing, SAE Technical Paper 2009-010103, 2009.

[2] BARLETT, W., WRIGHT, W. Yaw Tests on Pavement, Gravel, and Grass with ESC and ABS Braking, Proceedings of the 1st joint ITAI-EVU Conference, ITAI \& EVU Publishers, Hinckley, 2009, s. 201-207.

[3] BEAUCHAMP, G., HESSEL, D., ROSE, N. A., FENTON, R., FENTON, S. Determining Vehicle Steering and Braking from Yaw Mark Striations, SAE Technical Paper 2009-01-0092, 2009.

[4] HAGUE, D. J., LAMBOURN R.,F., TURNER D.,F. Critical Speed Studies I: The accuracy of speed calculated from critical curve marks and their striations. ITAI, Proceedings of the $3 r d$ National Conference, Telford, 14-16 November 1997.

[5] LAMBOURN, R. F. The calculation of motor car speeds from curved tyre marks. Journal of the Forensic Science Society 1986, 29, s. 371-386.

[6] LAMBOURN, R., JENNINGS, P., KNIGHT, I. Critical Speed Yaw Mark Calculations with and without Electronic Stability Control. Proceedings of the 1st joint ITAI-EVU Conference, ITAI \& EVU Publishers, Hinckley 2009, s. 209-235.

[7] Regulation No. 13 (UNECE), Uniform provisions concerning the approval of vehicles of categories $\mathrm{M}, \mathrm{N}$ and $\mathrm{O}$ with regard to braking. 
[8] RICHARDSON, S., ORTON, T., JOSEVSKI, N. A Critique of Critical Speed Yaw Mark Research, SAE Technical Paper 201201-0600, 2012.

[9] Wach W., Structural Reliability of Road Accidents Reconstruction), Institute of Forensic Research Pubisher, Kraków, 2014.

[10] SAE J211/1, Instrumentation for Impact Test - Part I - Electronic Instrumentation.
[11] www.racelogic.co.uk [Access: 14.10.2013].

[12] ZĘBALA, J., WACH, W. Lane Change Maneuver Driving a Car with Reduced Tyre Pressure, SAE Technical Paper No. 2014-010466, 2014.

[13] Zębala, J., Wach, W., Ciępka, P., Janczur, R. Bypassing Manoeuvre Driving a Car with Reduced and No Tire Pressure. Proceedings of the $22^{\text {th }}$ Annual Congress of EVU, Published by EVU, Firenze, 2013, s. 145-155.

\section{Správná citace:}

ZĘBALA, J., WACH, W., CIĘPKA, P., JANCZUR, R. Výpočty kritické rychlosti založené na smykových stopých zanechaných kolem s nulovým tlakem pneumatiky. Soudní inženýrství, 2018, 29(3), 13-20. ISSN 1211-443X. 